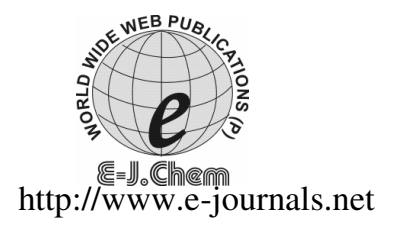

ISSN: 0973-4945; CODEN ECJHAO
E-Journal of Chemistry
2011, 8(4), 1680-1685

\title{
Spectrophotometric Method for the Determination of Carboxin in its Formulations and Environmental Samples
}

\author{
C.SWARNA, K.PURUSHOTHAM NAIDU, \\ G.NAGENDRUDU, N.V.S.NAIDU* and K.SARASWATHI \\ Department of Chemistry \\ S.V.University, Tirupathi-517502, A.P., India \\ swarnalahari@gmail.com
}

Received 17 February 2011; Accepted 16 April 2011

\begin{abstract}
Simple, precise, rapid, sensitive and accurate spectrophotometric methods have been developed for the estimation of carboxin in pure form and in its formulations. The first method is based on oxidative coupling of carboxin with 1,10-phenonthrolin in presence of ferric chloride to form orange colored product with $\lambda_{\max }$ of $510 \mathrm{~nm}$. The product obeyed Beer's law in the concentration range $1-10 \mathrm{~mL}(10$ to $100 \mu \mathrm{g} / \mathrm{mL})$ with molar absorptivity of $1.1425 \times 10^{3}$ Sandell's sensitivity 0.2061 . The second method is based on the reaction of carboxin with $2,2^{\prime}$-bipyridine to form orange red colored product exhibiting $\lambda_{\max }$ of $522 \mathrm{~nm}$ with molar absorptivity, Sandell's sensitivity $2.2605 \times 10^{3}, 0.1041$ respectively. It obeys Beer's law in the concentration range of $0.5-50 \mathrm{~mL}$ ( 5 to $50 \mu \mathrm{g} / \mathrm{mL}$ ). The assay of results was found to be in good agreement with label claim.
\end{abstract}

Keywords: Spectrophotometry, Carboxin, 1,10-Phenonthroline, 2,2'-Bipyridine, Ferric chloride, Orthophosphoric acid

\section{Introduction}

Carboxin (2,3-dihydro-6-methyl-oxathiin-5-carboxanilide, vitavax) is one of the several systemic fungicide (Figure 1) used in agriculture to control pathogenic fungi. Pesticides are widely used to protect the crops from a variety of pests. The use of pesticides benefits in increasing agricultural production but the repeated and indiscriminated use of certain pesticides have led to their accumulation in plants, animals, solid and sediments this effecting widespread contamination of the environment ${ }^{1}$. Such application of pesticides has the drawback of pesticide residues which remain in fruits and vegetables, constituting a potential risk to consumers. Fruits and vegetables are the foods that receive the highest doses of pesticides ${ }^{2}$. 
<smiles>CC1=C(C(=O)Nc2ccccc2)SCCC1</smiles>

Figure 1. Structure of carboxin

Carboxin is anilide fungicide and intensively applied at various stages of cultivation and during post harvest storage to provide protection against rotting ${ }^{3}$. Although it has low mammalian toxicity, fungicide residues levels in food stuffs are generally legislated to minimize the exposure of consumers to the harmful or unnecessary intake of pesticides ${ }^{3}$.

Most analytical methods for pesticide analysis are based on chromatographic techniques by both gas chromatography (GC) and high performance liquid chromatography (HPLC). HPLC is obviously preferred approach for polar less volatile and thermally labile pesticides such as carbamate. HPLC is an effective method for separating and analyzing the various carbamate pesticides employing different detectors ${ }^{4,5}$. Phototransformation of carboxin takes place when it is dissolved in water and it causes aquatic animals. Toxicity of the pesticide and its sulfoxide to aquatic organisms are reported ${ }^{6}$. The determination of pesticides applied in soya cultivation by using C8 co-column and subsequent chromatographic analysis by HPLC-DAD was developed. It proved that good recuperation for carboxin in soya cultivation ${ }^{7}$. Mechanism of action of carboxin and the development of resistance in yeast has already reported. Carboxin prevents the growth of yeast by inhibiting protein synthesis ${ }^{8}$. Carboxin and oxycarboxin undergo photolytic reactions in the presence of organic and inorganic soil components. Humic and fulvic acids in aqueous solution lead to enhanced photodegradation of carboxin ${ }^{9}$. The extraction of carboxin from cabbage samples using florisil sorbent solid phase extraction following with HPLC-UV analysis has been used as a reliable tool in residue analysis. The carboxin residues found in the cabbage sample with the safety label are likely to be lowerlevel than those in the sample without safety label ${ }^{10}$. All the above methods are expensive require long separation times for analysis. No spectrophotometric method is reported so far, for the determination of carboxin. In this work we adopted two simple spectrophotometric methods for the determination of carboxin in its food grains and water samples, formulations. These methods are based on the oxidation of carboxin with ferric chloride and subsequent chelation of the resulting iron(II) with 1,10-phenonthroline $\left(1^{\text {st }}\right.$ method) and with $2,2^{\prime}$-bipyridine $\left(2^{\text {nd }}\right.$ method). The resulting colored products were measured at $510 \& 522 \mathrm{nms}$ against the corresponding reagent blank respectively.

\section{Experimental}

A Shimadzu UV visible spectrophotometer (UV-2450) with $1 \mathrm{~cm}$ quartz cells was used for all the spectral measurements. All the chemicals used were of A.R. grade.

\section{Chemicals and reagent}

Methanol, 1,10-phenanthroline, ferric chloride, orthophosphoric acid, 2,2'-bipyridine is obtained from sigma aldrich and SD fine chemicals India. Sample of pesticide and internal standard were obtained from dhanuka agro chemicals limited Haryana, India respectively. Double distilled water was used to prepare all solutions for the method.

\section{Preparation of the standard solution}

About $100 \mathrm{mg}$ of carboxin pure or equivalent formulation powder was accurately weighed and dissolved in $20 \mathrm{~mL}$ of methanol filtered by whatman filter paper No 41 and to remove the insoluble matter. The residue was washed with $10 \mathrm{~mL}$ portions of methanol three times and the total volume of the filtrate was made up to $100 \mathrm{~mL}$ with methanol. The final working standard solution carboxin containing $1 \mu \mathrm{g} / \mathrm{mL}$ was prepared by using further dilutions. $0.2 \% \mathrm{FeCl}_{3}, 0.2 \mathrm{M}$ 1,10-PTL, 0.2 M 2,2-BPL, 0.1 $\mathrm{M} \mathrm{H}_{3} \mathrm{PO}_{4}$ were prepared for analysis. 


\section{General procedure}

\section{Method A}

Aliquots of standard pesticide solutions of carboxin ranging from $1-10 \mathrm{~mL}$ (10 to $100 \mu \mathrm{g} / \mathrm{mL}$ ) were transferred into a series of $10 \mathrm{~mL}$ of graduated tubes. To each tube $1 \mathrm{~mL}$ of $0.2 \mathrm{M}$ 1,10-phenonthroline solution was added followed by $1 \mathrm{~mL}$ of $(0.2 \%)$ ferric chloride solution and resulting solution was heated for $15 \mathrm{~min}$ at $100{ }^{\circ} \mathrm{C}$ and finally $1 \mathrm{~mL}(0.1 \mathrm{M})$ of orthophosphoric acid solution was added. The volume was made up to $10 \mathrm{~mL}$ with distilled water and the absorbance of the orange colored product was measured at $510 \mathrm{~nm}$ against reagent blank. The amount of carboxin present in the sample solution was computed from beer's law plot shown in Figure 1.

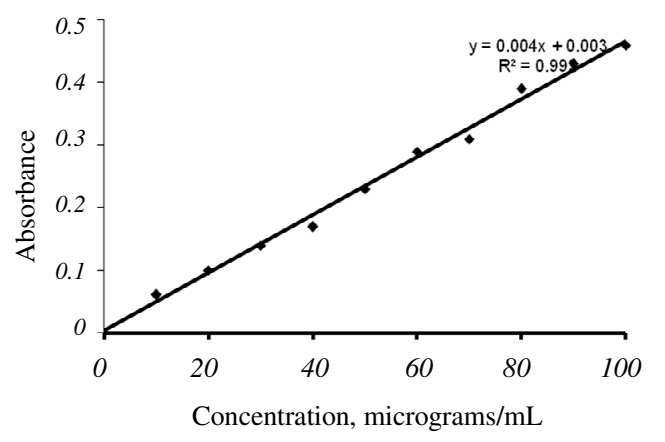

\section{Method B}

Figure 1. Calibration curve (Method A)

Aliquots of standard pesticide solutions of carboxin ranging from 0.5 to $50 \mathrm{~mL}$ ( 5 to $50 \mu \mathrm{g} / \mathrm{mL}$ ) were transferred into a series of $10 \mathrm{~mL}$ graduated tubes. To each tube $1 \mathrm{~mL}$ of 2,2'-bi pyridine solution was added followed by $1 \mathrm{~mL}(0.2 \%)$ of ferric chloride solution and the resulting solution was heated for $15 \mathrm{~min}$ at $100 \mathrm{c}$ and finally $1 \mathrm{~mL}(0.1 \mathrm{M})$ of orthophosphoric acid was added. The volume was made up to $10 \mathrm{~mL}$ with distilled water and the absorbance of the orange red colored product was measured at $522 \mathrm{~nm}$ against reagent blank. The amount of carboxin was computed from beer's law plot shown in Figure 2.

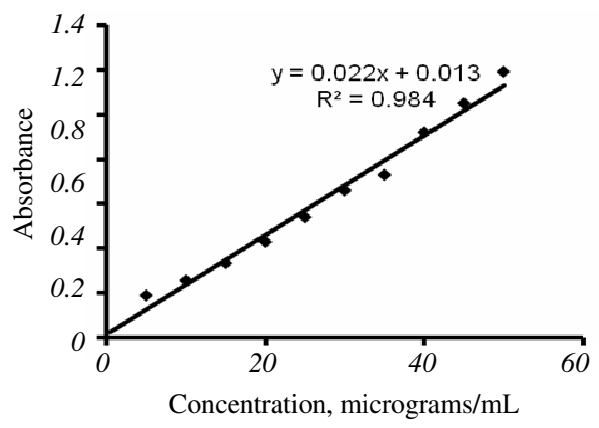

Figure 2. Calibration curve (Method B)

\section{Recovery of carboxin from spiked grains}

$100 \mathrm{~g}$ of each grain (Soybeans and Wheat) were spiked with $200 \mathrm{~mL}$ chloroform for $5 \mathrm{~min}$. The samples were fortified with different concentrations of carboxin in methanol and blended 
for $3 \mathrm{~min}$. Chloroform was filtered into $250 \mathrm{~mL}$ standard flask through Whatman No. 1 filter paper and the residue was retained. The residue was washed twice with $10 \mathrm{~mL}$ chloroform and blended for $2 \mathrm{~min}$. Chloroform extracts were combined and made up to the mark. Known aliquots of the chloroform extracts were used for color development after evaporating chloroform on a steam bath. The residue was dissolved in methanol and the amount was determined spectrophotometrically.

\section{Determination of recovery in fortified water samples}

After collection of the water sample (minimum volume one litre) the $\mathrm{pH}$ values were adjusted below 4 with $20 \% \mathrm{H} 2 \mathrm{SO} 4$. Then fortified with different concentrations of carboxin dissolved in methanol. Next extract each sample in a $250 \mathrm{~mL}$ separating funnel with $100 \mathrm{~mL}$ chloroform. The chloroform extract were transferred into a funnel and reextracted the aqueous phase twice with further $50 \mathrm{~mL}$ of chloroform. The second chloroform extract was added to the first and washed the combined extract with $0.1 \mathrm{M}$ potassium carbonate solution, then dried the chloroform by passing it through anhydrous sodium sulphate in a filter funnel and collected the extract in a $250 \mathrm{~mL}$ flask. The chloroform extract was reduced to $100 \mathrm{~mL}$.

\section{Results and Discussion}

The proposed methods involve the oxidation of carboxin with ferric chloride and subsequent complexation of resulting $\mathrm{Fe}^{2+}$ with 1,10-PTL in method $\mathrm{A}$ and with 2,2'-bipyridyl in method $\mathrm{B}$. $\mathrm{Fe}^{3+}$ (from $\mathrm{FeCl}_{3}$ ) oxidizes with carboxin and the produced $\mathrm{Fe}^{2+}$ forms a orange red colored complex, ferroin with 1,10-phenontheoline in method $\mathrm{A}$ which exhibits and absorption maximum at $510 \mathrm{~nm}$ and in method $\mathrm{B}$ the resulting orange red colored due to the formation of $\mathrm{Fe}^{2+}$. Bipy complex absorbs maximally at $522 \mathrm{~nm}$. In both methods the absorbance of the colored solution increases linearly with an increase in concentration of the carboxin.

The optical characteristics such as beer's law limits, molar absorptivity, Sandell's sensitivity, the regression analysis were made for the slope, intercept correlation and the results are shown in Table 1.

Table 1. Optical characteristics and validation data of spectrophotometric methods

\begin{tabular}{lcc}
\hline \multicolumn{1}{c}{ Parameters } & Method A & Method B \\
\hline$\lambda_{\max } \mathrm{nm}$ & 510 & 522 \\
Beer's Law limit, $\mu \mathrm{g} \mathrm{mL}^{-1}$ & $1.0-10$ & $0.05-5.0$ \\
Molar absorptivity, $\mathrm{L} \mathrm{mL}^{-1} \mathrm{~cm}^{-1}$ & $1.1425 \times 10^{3}$ & $2.2605 \times 10^{3}$ \\
Specific absorptivity & 0.00485 & 0.009606 \\
Sand ell's sensitivity, $\mu \mathrm{g} \mathrm{mL} \mathrm{mL}^{-1}$ & 0.2061 & 0.1041 \\
Regression equation & & \\
$\quad \mathrm{y}=\mathrm{bx}+\mathrm{c}$ ) & & \\
Slope (b) & 0.004 & 0.224 \\
Intercept ( C ) & 0.003 & 0.013 \\
Correlation coefficient ( $\mathrm{r}$ ) & 0.999 & 0.984 \\
Relative Standard & & \\
Deviation (R. S. D \%)* & 1.24 & 0.73 \\
Colour & Orange red & Orange red \\
\hline
\end{tabular}

Average of five determinations, ${ }^{* *} Y=b x+c$, Where $Y$ is the absorbance, $x$ is the concentration of the pesticide $\mu \mathrm{g} \mathrm{mL}^{-1}$ 
The proposed methods for the determination of carboxin were simple, accurate, linear, precise and reproducible and hence the methods can be successfully applied for the routine analysis of carboxin in its formulations, fortified water samples and food grains. The percentage results were shown in Tables $2,3 \& 4$.

Table 2. Determination of carboxin in formulations

\begin{tabular}{cccccc}
\hline \multirow{2}{*}{ Formulation } & Formulation, & \multicolumn{2}{c}{ Amount found in, $\mu \mathrm{g} / \mathrm{mL}$} & \multicolumn{2}{c}{ Recovery, \% } \\
\cline { 3 - 6 } & $\%$ & Method A & Method B & Method A & Method B \\
\hline Vitavax & 10 & 9.86 & 9.84 & 98.6 & 98.4 \\
& 20 & 19.89 & 19.68 & 99.45 & 98.40 \\
& 30 & 29.78 & 29.88 & 99.26 & 99.60 \\
& 40 & 39.92 & 39.89 & 99.80 & 99.70 \\
& 50 & 49.86 & 49.84 & 99.72 & 99.68 \\
\hline
\end{tabular}

Table 3. Recovery of carboxin from fortified water samples

\begin{tabular}{cccccc}
\hline & & \multicolumn{4}{c}{ Tap Water } \\
\cline { 3 - 6 } S.No. & $\begin{array}{c}\text { Fortification } \\
\text { level, } \mu \mathrm{g} / \mathrm{mL}\end{array}$ & $\begin{array}{c}\text { Amount of } \\
\text { found, } \mu \mathrm{g} / \mathrm{mL}\end{array}$ & $\begin{array}{c}\text { Recovery, } \\
\%\end{array}$ & $\begin{array}{c}\text { Amount of } \\
\text { found, } \mu \mathrm{g} / \mathrm{mL}\end{array}$ & $\begin{array}{c}\text { Recovery, } \\
\%\end{array}$ \\
\cline { 3 - 6 } & 0.5 & 0.49 & 98.0 & 0.48 & 96.0 \\
2 & 1.0 & 0.98 & 98.0 & 0.96 & 96.0 \\
3 & 1.5 & 1.49 & 99.3 & 1.47 & 98.0 \\
4 & 2.0 & 1.98 & 99.0 & 1.97 & 98.5 \\
5 & 2.5 & 2.48 & 99.2 & 2.46 & 98.4 \\
\hline
\end{tabular}

Table 4. Recoveries of carboxin added to (food grains) soyabeans and wheat

\begin{tabular}{|c|c|c|c|c|c|c|c|c|c|}
\hline \multirow[b]{3}{*}{$\underset{\dot{n}}{\stackrel{0}{z}}$} & \multirow{3}{*}{$\begin{array}{c}\text { Amount of } \\
\text { Carboxin } \\
\text { added } \mu \mathrm{g} / \mathrm{mL}\end{array}$} & \multicolumn{4}{|c|}{ Average amount found, $\mu \mathrm{g} / \mathrm{mL}$} & \multicolumn{4}{|c|}{ Recovery, \% } \\
\hline & & \multicolumn{2}{|c|}{ Method A } & \multicolumn{2}{|c|}{ Method B } & \multicolumn{2}{|c|}{ Method A } & \multicolumn{2}{|c|}{ Method B } \\
\hline & & $\underbrace{\tilde{\Xi}}_{i}$ & 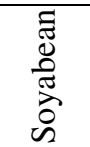 & $\begin{array}{l}\overrightarrow{\vec{J}} \\
\stackrel{3}{z}\end{array}$ & 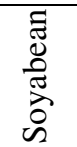 & 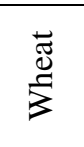 & 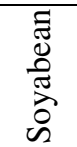 & $\begin{array}{l}\overrightarrow{\tilde{\Xi}} \\
\sum^{2}\end{array}$ & 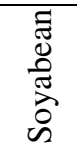 \\
\hline 1 & 2 & 1.92 & 1.93 & 1.96 & 1.99 & 97.0 & 96.5 & 98.0 & 99.0 \\
\hline 2 & 4 & 3.86 & 3.84 & 3.92 & 3.94 & 96.5 & 96.0 & 98.0 & 98.5 \\
\hline 3 & 6 & 5.92 & 5.94 & 5.89 & 5.89 & 98.6 & 99.0 & 97.0 & 98.1 \\
\hline 4 & 8 & 7.88 & 7.90 & 7.89 & 7.92 & 98.5 & 98.7 & 98.6 & 99.0 \\
\hline 5 & 10 & 9.92 & 9.95 & 9.88 & 9.94 & 99.2 & 99.5 & 98.8 & 99.4 \\
\hline
\end{tabular}

\section{Conclusion}

The spectrophotometric methods developed for the determination of carboxin was readily available and inexpensive. The methods are selective, sensitive and reproducible. Both methods are based on well characterized complexion reactions. Hence the proposed methods can be adopted for the routine analysis of the purity of the commercial formulations and environmental samples.

\section{Acknowledgment}

The authors are thankful to Dhanuka Agri Tech Pvt. Limited for providing the gift sample of carboxin and The Head Dept of Chemistry S.V.U., Tirupati for providing Instrument to carry out present work. 


\section{References}

1. Dalvi R R and Salunkhe D K, J Toxicol., 1975, 3(3), 269-285.

2. $\quad$ Torres C M, Pico Y and Manes J, J Chromatogr A, 1996, 754, 301-331.

3. Ana J G, Jordi M, Gurllermina F and Pico Y, J Chromatogr A, 2004, 1050, 119-127.

4. $\quad$ Wu J, Tragas C, Lord H and Pawliszyn J, J Chromatogr A, 2002, 976, 357-367.

5. Brian A B, Practical HPLC Methodology and Applications. John Wiley and Sons., New York, 1992.

6. Marina Dellagreca, Maria Rosaria lesce, Flavio Cermola, Maria Rubino and Marina lsidori, J Agric Food Chem., 2004, 52(20), 6228-6232.

7. Liane Maldaner, Cesar C Santana, Isabel C S F Jardim, J Liq Chromatogr Relat Technol., 2008, 31(7), 972-983.

8. Gunasekaran P and Tauro P, J Biosci., 1982, 4(2), 219-225.

9. Hustert K, Moza P N and Kettrup A, Chemosphere, 1999, 38, 3423-3429.

10. Khin L, Zan and Somporn Chantara, Chiang Mai J Sci., 2007, 34(2), 227-234. 


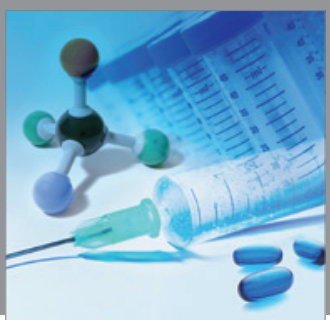

International Journal of

Medicinal Chemistry

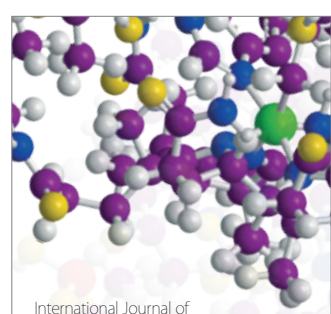

Carbohydrate Chemistry

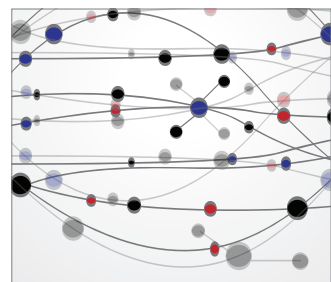

The Scientific World Journal
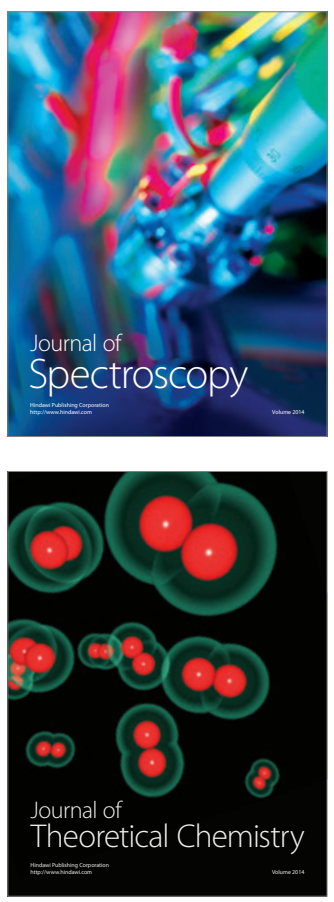
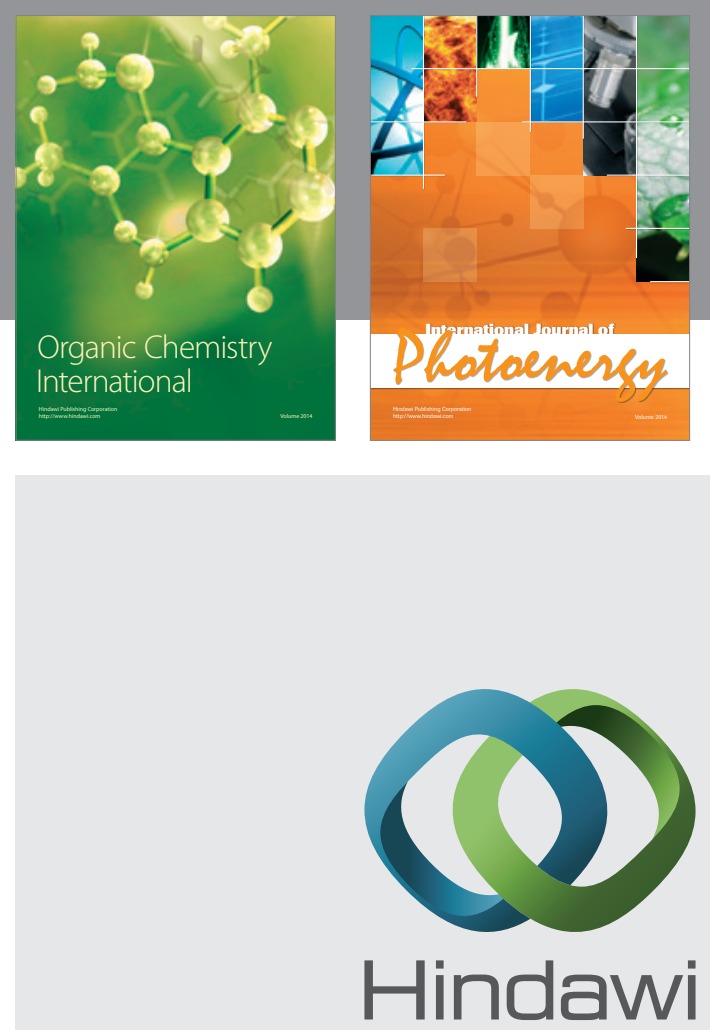

Submit your manuscripts at

http://www.hindawi.com
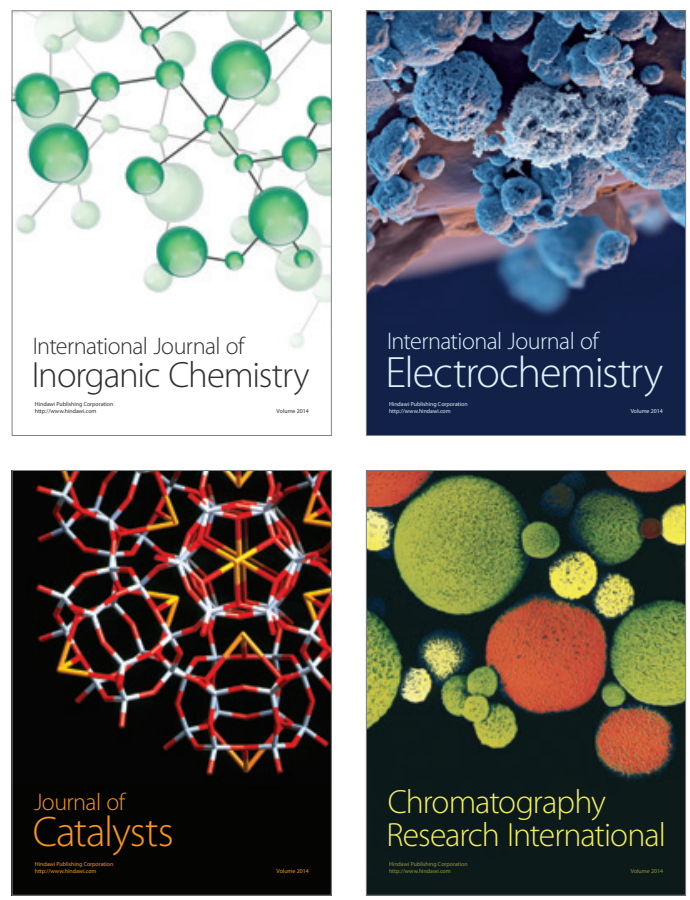
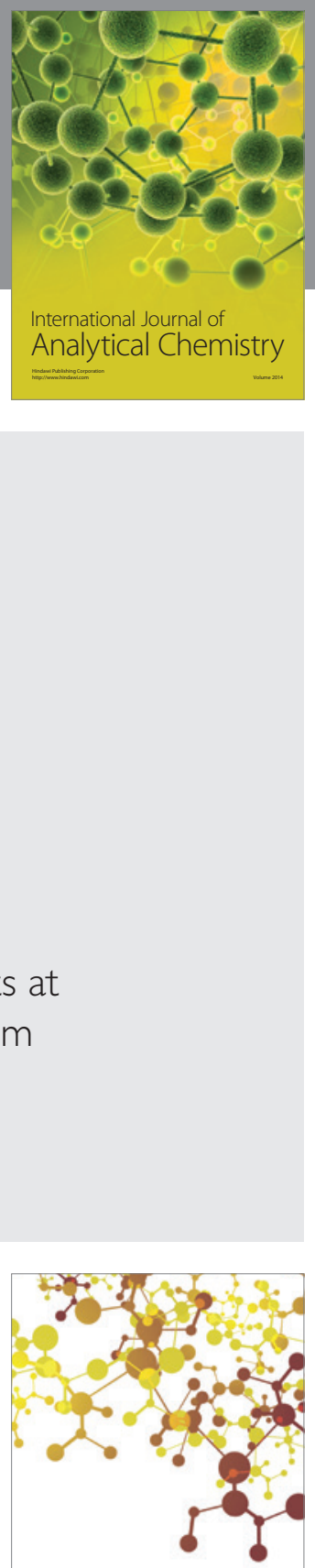

Journal of

Applied Chemistry
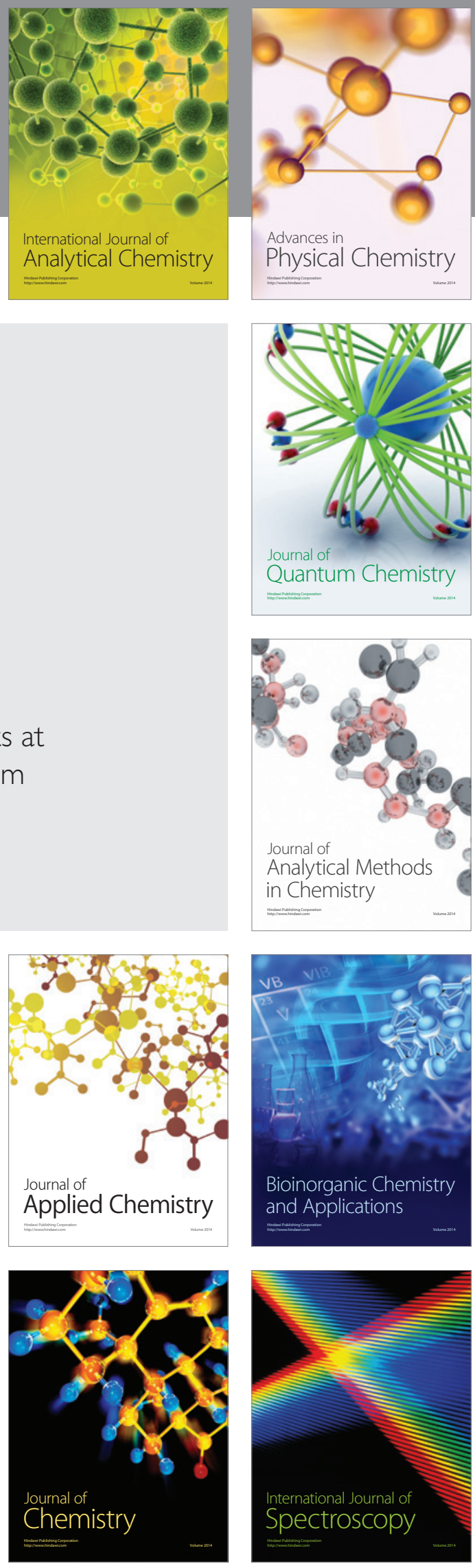